\title{
Primary Personal Finance Problem in Indonesia
}

\author{
Agus Suroso ${ }^{1^{*}}$, Ascaryan Rafinda ${ }^{2}$, Timea $\mathrm{Gal}^{3}$, and Osama Alhendi ${ }^{4}$ \\ ${ }^{1}$ Faculty of Economics and Business Universitas Jenderal Soedirman, Indonesia \\ ${ }^{2}$ University of Debrecen, Károly Ihrig Doctoral School of Management and Business, Hungary \\ ${ }^{3}$ The Islamic University of Gaza, Palestine \\ ${ }^{4}$ University of Debrecen, Károly Ihrig Doctoral School of Management and Business, Hungary
}

\begin{abstract}
The main objective of this research is to find out primary personal finance problem in Indonesia. A lot of people do not realize that they need financial knowledge to make financial decision. It leads to bounded rationality when they do the financial decision. Financial problem commonly not different years by years, then by collection financial problem this research could spread and warn other people not to fall into same problem. This research collecting data by questionnaire. Total 360 respondent fill in the questionnaire. The result successfully identify there are several topics in personal finance that become main problem. There are, have no finance plan, debt management and excessive spending. This research imply that we should focus on that topic on educating people in personal finance.
\end{abstract}

\section{Introduction}

National survey results show that only $29.66 \%$ of Indonesian people financially well litarated (Otoritas Jasa Keuangan, 2016). The total population of Indonesia is more than 220 million people, indicating less than 66 million people have good level of financial literacy. The low level of financial literacy makes a person unable to maximize the potential in financial decision making (Mandell \& Klein, 2007). Further impact when a person is unable to make financial decisions to the fullest is the poor planning of pension funds and the low accumulation of assets (Lusardi, 2005), the amount of borrowing costs (J. Hastings, Mitchell, \& Chyn, 2010), mistakes in choosing personal investment instruments (M. van Rooij, Lusardi, \& Alessie, 2011).

Financial education important do reduce the possibility of poor financial decision making. The Indonesian government is expected to build the foundation of financial education. Through the financial services authority, the Indonesian government promotes the importance of financial education. Various financial modules and financial literacy guidelines have emerged in Indonesia. Various agencies and non-profit institutions participate in increasing public financial literacy. But it is unfortunate because the financial module explain the general of finance and not developed based on real financial problems or cases in the community.

\footnotetext{
* Corresponding author: roso.fe2014@gmail.com
} 
This research identifies various real financial problems that faced by Indonesian society. In the future data of this research can be used as a database of financial problems in Indonesian society. Focusing on people at vulnerable ages between 23-45 years old this research collected data from a total of 360 participants, collected financial problems faced by people in Indonesia. The results of this research found that there are three topics that are the main problems of the people in Indonesia.

\section{Literature Review}

Previous research in the field of personal finance has focused on antecedents and consequences. Various antecedent topics from personal finance discuss the factors that can enhance personal finance knowledge. Various factors has been found such as family, environment and friends are factors that can increase personal finance knowledge (Bowen, 2002; Chen \& Volpe, 2002; Norvilitis \& MacLean, 2010; Shim, Serido, Bosch, \& Tang, 2013; Xiao, Tang, Serido, \& Shim, 2011).

Previous research in the field of personal finance that focuses on consequences focuses on discussing financial behaviour. The research focuses on the impact of someone who has personal finance knowledge on his financial behaviour. Various studies have found that low personal finance knowledge has an impact on poor financial decision making (J. Hastings et al., 2010; Lusardi, 2005; Mandell \& Klein, 2007; Opletalová, 2015; M. C. J. van Rooij, Lusardi, \& Alessie, 2012).

There are three most common factors that can increase a personal finance knowledge. Family, friends and the environment are factors that has been found could influence a person's financial knowledge. But not everyone has the same opportunity to get family, friends and environment that support financially. Therefore financial education is one of the alternative factors that can be used to improve people financial knowledge.

Research on financial education is usually related to financial literacy and financial outcomes. The results of a review on various empirical studies found that there are no clear cut results between the three of them (Álvarez-franco et al., 2017). Other research findings found that there is no way to conclude the relationship between financial education, financial literacy and financial outcomes (Fernandes, Lynch, \& Netemeyer, 2014; J. S. Hastings, Madrian, \& Skimmyhorn, 2013; Kaiser \& Menkhoff, 2017; Miller, Reichelstein, Salas, \& Zia, 2015). Various problems of the relationship between financial education with financial literacy and financial outcomes can occur because of the non-specific financial training material provided. So that participants do not get material in accordance with expectations and real financial problems encountered.

This research was conducted to identify the real financial cases in Indonesia. The identification of various financial cases makes it easy for educators to develop real casebased financial education. In the future participants who get a real case of financial problems, they are expected to be able to anticipate these problems in the future.

\section{Research Method}

The data collection was carried out using an online questionnaire. The questionnaire was distributed conveniently through the closest relatives and colleagues. Various social media and chatting applications were used in the process of disseminating research instruments. Social media like Instagram and Facebook were used to process information dissemination, as well as WhatsApp chat applications.

The instrument consists of 20 questions covering 1) demographics (8 questions), 2) financial background (4 questions) and 3) financial education (6 questions). There are two 
types of questions, namely multiple choice and description. Each participant needs 10-20 minutes to complete filling in the research instrument.

Before collecting the real sample, pilot test was conducted to check the research instrument. A pilot test was conducted on 37 people to identify the level of understanding and the possibility of multi perception of each question asked. The results of the pilot test, carried out minor revisions in several terms to make it easier for participants to understand.

The data collection process was carried out for 40 days, instruments prepared online were disseminated through the closest relatives and colleagues. In an effort to increase participation, selected participants will get incentives with a predetermined category. A total of 10 participants were selected to receive incentives as appreciation for the answers given. A total of 360 participants had heterogeneous respondent demographics.

This research examine using content analysis to understand various financial problems in Indonesia. Content analysis was done by understanding the answers regarding financial problems faced by respondents. This research uses keywords to facilitate the classification of existing problems. For example, a problem falls into the category of debt management when keywords appear, such as debt, credit, instalments, etc. Classification is carried out following the problems that arise from the results of research. There are no restrictions in the process of grouping financial problems.

After classifying based on financial cases, the next step is to determine priorities. Total 5 cases of financial problems arise using keywords. This research counts the number of cases that come out based on data obtained. For example, there are cases of debt management, personal cost management and, personal investments. This research calculate the number of that three cases. The more people fill in regarding personal investments, then the topic will raise and become priority case and vice versa.

\section{Result and Discussion}

Content analysis was carried out to classify financial problems. From a total of 360 participants, classification was carried out into 5 topics. The following is a list of topics and keywords used in classification:

Table 1. Keywords that used to classify the problem

\begin{tabular}{c|ll}
\multicolumn{1}{c}{ No } & \multicolumn{1}{c}{ Topic } & \multicolumn{1}{c}{ Keywords } \\
\hline 1 & Debt Management & Credit, Loans, Installments \\
2 & Saving & $\begin{array}{l}\text { Reserve Funds, Idle Money, Emergency } \\
\text { Funds }\end{array}$ \\
3 & Investment & $\begin{array}{l}\text { Side Income, passive income, maximize idle } \\
\text { funds }\end{array}$ \\
4 & $\begin{array}{l}\text { Expense } \\
\text { Difficulties manage money, run out before } \\
\text { end of months }\end{array}$ \\
5 & $\begin{array}{l}\text { Management } \\
\text { Financial Planning }\end{array}$ & Have no plan, have no financial target.
\end{tabular}

These five topics are the main focus of this research. The next step is calculate the number of cases that arise from each topic of financial problems. The following are the number of cases that emerged based on data collected: 
Table 2. Number of cases on Financial Topics

\begin{tabular}{|c|c|c|}
\hline No & Topic & Number of Cases \\
\hline 1 & Debt Management & 136 \\
\hline 2 & Saving & 72 \\
\hline 3 & Investment & 48 \\
\hline 4 & Expense Management & 54 \\
\hline \multirow[t]{2}{*}{5} & Financial Planning & 50 \\
\hline & & 360 \\
\hline
\end{tabular}

Debt management is the most common case based on the results of this research. This shows that many debt problems must be resolved by the Indonesian. In this debt topic, there are various sub-topics of debt that are very specific such as the management of mortgage payments, calculation of vehicle debt instalments, etc.

Identification of these sub-topics is important for further research. This is because the sub-topic database will be used as financial education media in the future based on real cases. Financial education based on real cases will make education participants understand well what the actual conditions in Indonesia.

\section{Implication and Limitation}

This research has identified various financial problems that faced by Indonesian society. Having discovered various specific financial problems, further implications are the potential for the development of real case-based financial education media. Real cases collected from the results of this research become a database in the development of financial education. So it is hoped that financial education participants can benefit directly.

\section{References}

[1] P. B. Alvarez Franco, A. M. Muñoz Murillo, and D. A. Restrepo Tobón, Cuad. Adm. 30, (2017)

[2] C. Faulcon Bowen, J. Financ. Couns. Plan. (2002)

[3] H. Chen and R. Volpe, Financ. Serv. Rev. (2002)

[4] D. Fernandes, J. G. Lynch, and R. G. Netemeyer, Manage. Sci. 60, 1861 (2014)

[5] J. Hastings, O. S. Mitchell, and E. Chyn, in Financ. Lit. Implic. Retire. Secur. Financ. Marketpl. (Oxford University Press, 2011)

[6] J. S. Hastings, B. C. Madrian, and W. L. Skimmyhorn, Annu. Rev. Econom. 5, 347 (2013)

[7] T. Kaiser and L. Menkhoff, World Bank Econ. Rev. 31, 611 (2017)

[8] A. Lusardi, in Pension Des. Struct. (Oxford University Press, 2004)

[9] L. Mandell and L. S. Klein, Financ. Serv. Rev. (2007)

[10] M. Miller, J. Reichelstein, C. Salas, and B. Zia, World Bank Res. Obs. 30, 220 (2015)

[11] J. M. Norvilitis and M. G. MacLean, J. Econ. Psychol. 31, 55 (2010) 
[12] A. Opletalová, Procedia - Soc. Behav. Sci. 171, 1176 (2015)

[13] Otoritas Jasa Keuangan, Surv. Rep. (2016)

[14] S. SHIM, J. SERIDO, L. BOSCH, and C. TANG, J. Consum. Aff. 47, 128 (2013)

[15] M. C. J. van Rooij, A. Lusardi, and R. J. M. Alessie, Econ. J. 122, 449 (2012)

[16] M. van Rooij, A. Lusardi, and R. Alessie, J. Financ. Econ. 101, 449 (2011)

[17] J. J. Xiao, C. Tang, J. Serido, and S. Shim, J. Public Policy Mark. 30, 239 (2011) 